\title{
Quinidine-associated skin discoloration in KCNT1-associated pediatric epilepsy
}

\section{Figure Skin discoloration after 9 months of quinidine use}
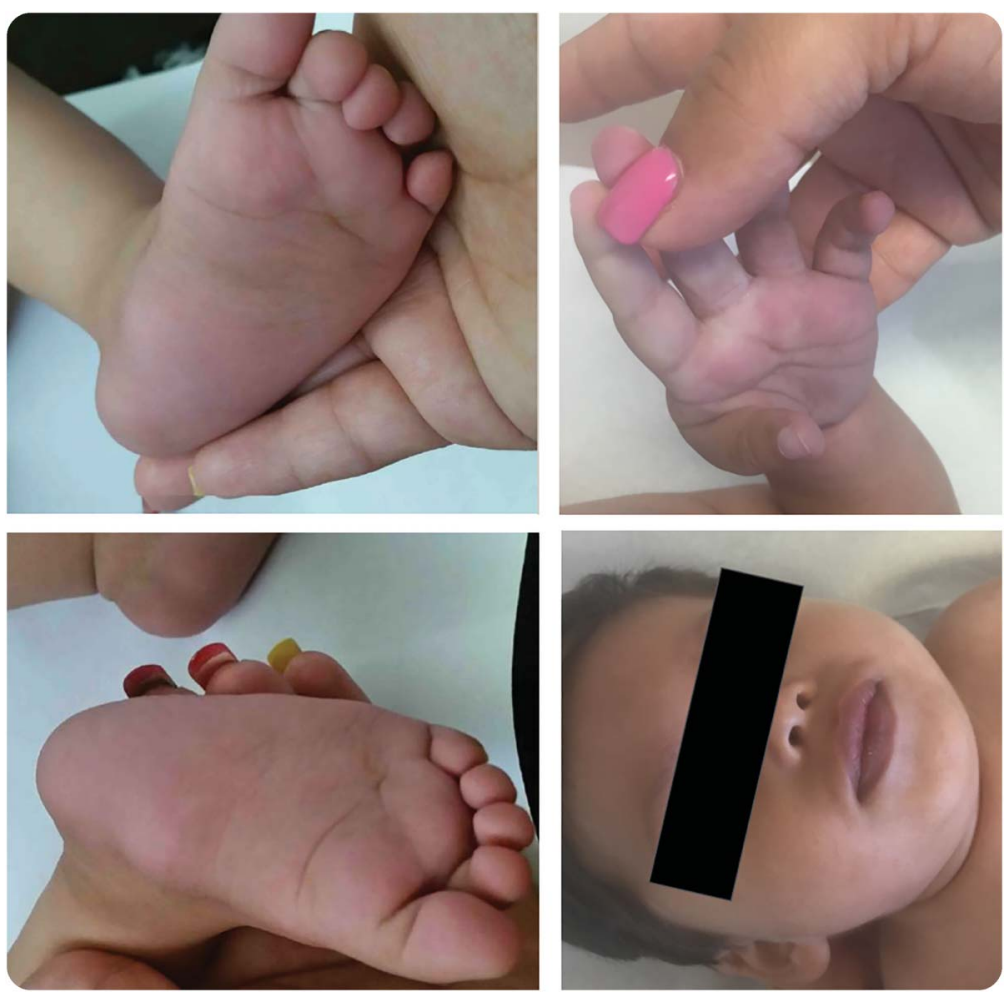

The patient developed bluish discoloration of the hands, feet, and lips in a similar distribution to that seen in ezogabinerelated skin discoloration. The sclerae were not affected. A dilated retinal examination has not been performed due to the severity of the patient's illness.

A 9-month-old boy with migrating partial seizures of infancy due to a de novo KCNT1 mutation c.2278A > T (p.Ile760Phe) developed bluish discoloration of the hands, feet, and lips (figure) during a 9-month trial of quinidine $(40 \mathrm{mg} / \mathrm{kg} / \mathrm{d}$; level $3.4 \mu \mathrm{g} / \mathrm{mL}) .{ }^{1}$ There was no exposure to other medications that cause pigmentary changes. Given minimal improvement in seizures and development, quinidine was stopped. Discoloration persisted at 3 months but markedly improved by the 6-month follow-up. Though common with other potassium channel blockers (ezogabine and quinine), such discoloration has only rarely been reported with quinidine, all in adults. ${ }^{2}$ Epileptologists should be aware of this potential complication of quinidine therapy.

Fiona M. Baumer, MD, Maureen Sheehan, NP

From the Department of Neurology (F.M.B.) and Lucile Packard Children’s Hospital (F.M.B., M.S.), Stanford University Medical School, CA.

Author contributions: Fiona Baumer: prepared manuscript and took photographs. Maureen Sheehan: critically revised manuscript.

Study funding: Fiona Baumer is supported by a KL2 Mentored Career Development Award of the Stanford Clinical and Translational Science Award to Spectrum (NIH KL2 TR 001083) and UL1 TR 001085.

Disclosure: The authors report no disclosures relevant to the manuscript. Go to Neurology.org for full disclosures.

Correspondence to Dr. Baumer: fbaumer@stanford.edu

1. Bearden D, Strong A, Ehnot J, DiGiovine M, Dlugos D, Goldberg EM. Targeted treatment of migrating partial seizures of infancy with quinidine. Ann Neurol 2014;76:457-461.

2. Conroy EA, Liranzo MO, McMahon J, Steck WD, Tuthill RJ. Quinidine-induced pigmentation. Cutis 1996;57:425-427. 


\section{Neurology}

\section{Quinidine-associated skin discoloration in $K C N T 1$-associated pediatric epilepsy \\ Fiona M. Baumer and Maureen Sheehan \\ Neurology 2017;89;2212 \\ DOI 10.1212/WNL.0000000000004674}

This information is current as of November 20, 2017

\begin{tabular}{|c|c|}
\hline $\begin{array}{l}\text { Updated Information \& } \\
\text { Services }\end{array}$ & $\begin{array}{l}\text { including high resolution figures, can be found at: } \\
\text { http://n.neurology.org/content/89/21/2212.full }\end{array}$ \\
\hline References & $\begin{array}{l}\text { This article cites } 2 \text { articles, } 0 \text { of which you can access for free at: } \\
\text { http://n.neurology.org/content/89/21/2212.full\#ref-list-1 }\end{array}$ \\
\hline Citations & $\begin{array}{l}\text { This article has been cited by } 3 \text { HighWire-hosted articles: } \\
\text { http://n.neurology.org/content/89/21/2212.full\#\#otherarticles }\end{array}$ \\
\hline Subspecialty Collections & $\begin{array}{l}\text { This article, along with others on similar topics, appears in the } \\
\text { following collection(s): } \\
\text { Antiepileptic drugs } \\
\text { http://n.neurology.org/cgi/collection/antiepileptic_drugs }\end{array}$ \\
\hline Errata & $\begin{array}{l}\text { An erratum has been published regarding this article. Please see next } \\
\text { page or: } \\
\text { /content/90/23/1084.1.full.pdf }\end{array}$ \\
\hline Permissions \& Licensing & $\begin{array}{l}\text { Information about reproducing this article in parts (figures,tables) or in } \\
\text { its entirety can be found online at: } \\
\text { http://www.neurology.org/about/about_the_journal\#permissions }\end{array}$ \\
\hline Reprints & $\begin{array}{l}\text { Information about ordering reprints can be found online: } \\
\mathrm{http} / / / \mathrm{n} \text {.neurology.org/subscribers/advertise }\end{array}$ \\
\hline
\end{tabular}

Neurology ${ }^{\circledR}$ is the official journal of the American Academy of Neurology. Published continuously since 1951, it is now a weekly with 48 issues per year. Copyright () 2017 American Academy of Neurology. All rights reserved. Print ISSN: 0028-3878. Online ISSN: 1526-632X.

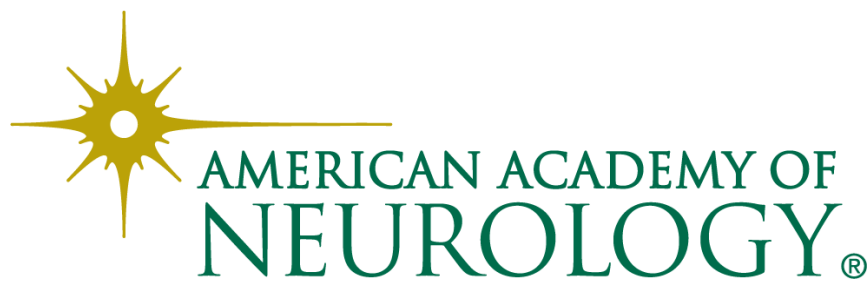




\section{Quinidine-associated skin discoloration in KCNT1-associated pediatric epilepsy}

Neurology ${ }^{\circledR}$ 2018;90:1084. doi:10.1212/WNL.0000000000005628

In the NeuroImage "Quinidine-associated skin discoloration in KCNT1-associated pediatric epilepsy" by Baumer and Sheehan, ${ }^{1}$ there is an error in the second to last sentence, which should have referred to ezobagine and quinine as potassium channel agents rather than potassium channel blockers as originally published. The authors regret the error.

\section{Reference}

1. Baumer FM, Sheehan M. Quinidine-associated skin discoloration in KCNT1-associated pediatric epilepsy. Neurology 2017;89:2212.

\section{The genetic basis of undiagnosed muscular dystrophies and myopathies: Results from 504 patients}

Neurology ${ }^{\circledR}$ 2018;90:1084. doi:10.1212/WNL.0000000000005192

In the article "The genetic basis of undiagnosed muscular dystrophies and myopathies: Results from 504 patients" by M. Savarese et al., ${ }^{1}$ there is an error in the 21st author's name, which should have read "Simone Sampaolo" rather than "Simone Sanpaolo" as originally published. The authors regret the error.

\section{Reference}

1. Savarese M, Di Fruscio G, Torella A, et al. The genetic basis of undiagnosed muscular dystrophies and myopathies: Results from 504 patients. Neurology 2016;87:71-76.

\section{Outcome of intracerebral hemorrhage associated with different oral anticoagulants \\ Neurology ${ }^{\circledR}$ 2018;90:1084. doi:10.1212/WNL.0000000000004976}

In the article "Outcome of intracerebral hemorrhage associated with different oral anticoagulants" by D. Wilson et al., ${ }^{1}$ there are typographical errors in the rate of hematoma expansion within the study cohorts. The second to last sentence of the Abstract should read "...the rate of HE (NOAC-ICH n $=19 / 48$ [40\%] vs VKA-ICH n $=47 / 140$ [34\%])" rather than "29/48 [40\%]" and "93/140 [34\%]," respectively, as originally published. Likewise, the third sentence under "Secondary outcomes" in the Results section should read "... and did not vary by anticoagulant type (NOAC-ICH 19/48 40\% vs VKA-ICH 47/140 34\%, $p=0.45$ )” rather than " $29 / 4840 \%$ " and "93/140 34\%" as originally published. The authors regret the errors.

\section{Reference}

1. Wilson D, Seiffge DJ, Traenka C, et al. Outcome of intracerebral hemorrhage associated with different oral anticoagulants. Neurology 2017;88:1693-1700. 